\title{
Quantification of black carbon mixing state from traffic: implications for aerosol optical properties
}

\author{
Megan D. Willis ${ }^{1}$, Robert M. Healy ${ }^{2,3, a}$, Nicole Riemer ${ }^{4}$, Matthew West ${ }^{5}$, Jon M. Wang ${ }^{2}$, Cheol-Heon Jeong ${ }^{2}$, \\ John C. Wenger ${ }^{3}$, Greg J. Evans ${ }^{2}$, Jonathan P. D. Abbatt ${ }^{1}$, and Alex K. Y. Lee ${ }^{1}$ \\ ${ }^{1}$ Department of Chemistry, University of Toronto, Toronto, Ontario, Canada \\ ${ }^{2}$ Southern Ontario Centre for Atmospheric Aerosol Research, Department of Chemical Engineering and Applied Chemistry, \\ University of Toronto, Toronto, Ontario, Canada \\ ${ }^{3}$ Department of Chemistry and Environmental Research Institute, University College Cork, Cork, Ireland \\ ${ }^{4}$ Department of Atmospheric Sciences, University of Illinois at Urbana-Champaign, Urbana, USA \\ ${ }^{5}$ Department of Mechanical Science and Engineering, University of Illinois at Urbana-Champaign, Urbana, USA \\ ${ }^{a}$ now at: Air Monitoring and Transboundary Air Sciences Section, Environmental Monitoring and Reporting Branch, Ontario \\ Ministry of the Environment and Climate Change, Toronto, Ontario, Canada
}

Correspondence to: Megan D. Willis (megan.willis@mail.utoronto.ca) and Alex K. Y. Lee (alexky.lee@utoronto.ca)

Received: 11 November 2015 - Published in Atmos. Chem. Phys. Discuss.: 27 November 2015

Revised: 1 April 2016 - Accepted: 6 April 2016 - Published: 14 April 2016

\begin{abstract}
The climatic impacts of black carbon (BC) aerosol, an important absorber of solar radiation in the atmosphere, remain poorly constrained and are intimately related to its particle-scale physical and chemical properties. Using particle-resolved modelling informed by quantitative measurements from a soot-particle aerosol mass spectrometer, we confirm that the mixing state (the distribution of co-emitted aerosol amongst fresh BC-containing particles) at the time of emission significantly affects BC-aerosol optical properties even after a day of atmospheric processing. Both single particle and ensemble aerosol mass spectrometry observations indicate that $\mathrm{BC}$ near the point of emission co-exists with hydrocarbon-like organic aerosol (HOA) in two distinct particle types: HOA-rich and BC-rich particles. The average mass fraction of black carbon in HOA-rich and $\mathrm{BC}$-rich particle classes was $<0.1$ and 0.8 , respectively. Notably, approximately $90 \%$ of BC mass resides in BC-rich particles. This new measurement capability provides quantitative insight into the physical and chemical nature of $\mathrm{BC}$ containing particles and is used to drive a particle-resolved aerosol box model. Significant differences in calculated single scattering albedo (an increase of 0.1) arise from accurate treatment of initial particle mixing state as compared to the assumption of uniform aerosol composition at the point of $\mathrm{BC}$ injection into the atmosphere.
\end{abstract}

\section{Introduction}

Incomplete combustion emits teragram quantities of black carbon (BC) aerosol to the troposphere each year, resulting in a significant warming effect on climate that may be second only to carbon dioxide (Bond et al., 2013; Ramanathan and Carmichael, 2008; Jacobson, 2001). BC influences climate directly, by absorbing solar radiation, and indirectly, by changing cloud properties and altering snow and ice melt. BC impacts on the global scale remain poorly constrained and are intimately related to its particle-scale physical and chemical properties (Bond et al., 2013). The majority of BC emissions in North America, Europe, and Latin America are derived from traffic-related sources, though the specific physical and chemical properties of BC-containing particles at emission depend greatly on the source (Bond et al., 2013). BC-containing particles are generally hydrophobic near emission and become mixed over time with hydrophilic species through condensation and coagulation (Johnson et al., 2005; Moteki et al., 2007; Moffet and Prather, 2009), with resulting impacts on particle hygroscopicity (McMeeking et al., 2011b; D. Liu et al., 2013; Laborde et al., 2013) and optical properties (Zhang et al., 2008; Cappa et al., 2012; Lack et al., 2012; Knox et al., 2009; Liu et al., 2015). Despite extensive previous work, our understanding of the 
role of mixing state in influencing the climate impacts of $\mathrm{BC}$ remains incomplete, in part because of instrumental challenges in particle characterization.

Studies assessing both the composition and amount of non-BC species in BC-containing particles are rare. A large body of evidence from urban, tunnel, and engine emission studies has shown that individual combustion particles are mixtures of $\mathrm{BC}$, inorganic species, metals, and hydrocarbonlike organic species at the time of emission (e.g., Johnson et al., 2005; Toner et al., 2006; Schneider et al., 2006; Tritscher et al., 2011; Chirico et al., 2010; Zhang et al., 2013; Massoli et al., 2012; Dallmann et al., 2014). Among these studies, single particle mass spectrometry has directly demonstrated mixing of $\mathrm{BC}$ and non-BC species in trafficderived particles. For example, Toner et al. (2006) observed that emissions from heavy duty diesel engines were dominated by particles containing BC, organic species, calcium, and phosphate, with one particle type dominated by $\mathrm{BC}$ and another with higher levels of organic species. In contrast, Healy et al. (2012) observed BC-dominated particles from traffic emissions in a European city. Other approaches to measure $\mathrm{BC}$ mixing state, including hygroscopicity and volatility differential mobility techniques, have highlighted the presence of an external mixture in terms of particle volatility with lower volatility, BC-containing aerosol being less hygroscopic (Kuwata et al., 2009; McMeeking et al., 2011a). Further, single particle soot photometer measurements of coating thickness in urban areas have shown that traffic-related BC-containing particles are largely uncoated or very thinly coated (Shiraiwa et al., 2008; McMeeking et al., 2011b; Laborde et al., 2013; Liu et al., 2014). In addition, microscopy studies have illustrated the dominance of bare or thinly coated BC-containing particles in traffic emissions (China et al., 2014) and the occurrence of coating, embedding and compaction of $\mathrm{BC}$ as it is aged (Adachi and Buseck, 2013; Adachi et al., 2014). While previous work has provided valuable insight into $\mathrm{BC}$ mixing state, the majority of past approaches have not allowed simultaneous quantification of $\mathrm{BC}$ mixing state on a mass basis and chemical characterization of non-BC species.

Considerable attention has been paid to BC-containing aerosol because of the potential for short-term climate mitigation through emission reduction (Shindell et al., 2012). Therefore, a quantitative understanding of $\mathrm{BC}$ mixing state is crucial for three reasons: first, to assess rates of $\mathrm{BC}$ processing and removal in the atmosphere; second, to assess the role that $\mathrm{BC}$-containing particles play as cloud nuclei; and third, to assess direct effects on solar radiation. Aerosol optical properties are central parameters required to evaluate direct radiative forcing (DRF). One of the largest contributors to uncertainty in DRF calculations is the single scattering albedo (SSA) (McComiskey et al., 2008), defined as the ratio of aerosol scattering to total light extinction. Previous work has clearly demonstrated that calculations of aerosol optical properties depend upon assumptions about particle mixing state (e.g., Jacobson, 2000), with assumptions of uniform internal mixing producing overestimates of absorption efficiency and underestimates of single scattering albedo (Oshima et al., 2009; Zaveri et al., 2010; Matsui et al., 2013). The role of $\mathrm{BC}$-aerosol mixing state at emission in affecting its mixing state in the atmosphere has also been highlighted in modelling studies explicitly treating detailed aerosol microphysical and chemical processes (e.g., Matsui et al., 2013). However, model assessments driven by quantitative measurements of aerosol mixing state remain rare.

In this work, we use a soot-particle aerosol mass spectrometer, equipped with a light-scattering module, to determine the mixing state of $\mathrm{BC}$-containing particles from trafficdominated sources in an urban environment. These measurements provide quantitative insight into the physical and chemical nature of $\mathrm{BC}$-containing particles near emission, and they are used to drive a particle-resolved aerosol box model to assess the effect of accurately representing BC mixing on aerosol optical properties.

\section{Methods}

\subsection{The soot-particle aerosol mass spectrometer (SP-AMS)}

\subsubsection{Two urban studies: locations and SP-AMS configuration}

A soot-particle aerosol mass spectrometer (Aerodyne Research Inc., Billerica, MA, USA), equipped with a light scattering module, was deployed in two urban studies to assess the mixing state of refractory black carbon (rBC) containing particles derived from vehicle emissions (Lee et al., 2015a). The first study was conducted in downtown Toronto away from major roadways (referred to as the "non-roadside" study), and the second was performed at ground level, near a busy road in downtown Toronto (referred to as the "roadside" study), to investigate fresh vehicle emissions. The nonroadside site is described in detail in Lee et al. (2015a). The roadside study took place from 31 May to 24 June 2013 at the Southern Ontario Centre for Atmospheric Aerosol Research (SOCAAR) facility in downtown Toronto, Canada, located at ground level and adjacent to a road with traffic volumes ranging from 16000 to 25000 vehicles per day (Sabaliauskas et al., 2014). Ambient air was sampled at $170 \mathrm{~L} \mathrm{~min}^{-1}$ through a $10 \mathrm{~cm}$ (inner diameter) stainless steel tube fitted with a $2.5 \mu \mathrm{m}$ cut-off inlet, located $15 \mathrm{~m}$ from the roadside at a height of $3 \mathrm{~m}$ a.g.l.

Two main modes of operation are possible with the SPAMS, depending on the vaporizer configuration. The instrument was operated such that both $\mathrm{rBC}$-containing particles and non-rBC-containing particles were detected in the nonroadside study (i.e., a dual-vaporizer configuration), whereas exclusively $\mathrm{rBC}$-containing particles were detected in the 
roadside study (i.e., a laser-only configuration) (Lee et al., 2015a; Onasch et al., 2012).

\subsubsection{SP-AMS operation and calibration}

Details of the SP-AMS (and SP-AMS with light scattering) have been described elsewhere (Lee et al., 2015a; Onasch et al., 2012). The SP-AMS detects black carbon, which evaporates at $\sim 4000 \mathrm{~K}$, as $\mathrm{C}_{x}^{+}$fragments (predominantly $\mathrm{m} / z 12$, $24,36,48$, and 60 ) and is referred to as refractory black carbon (rBC) (Onasch et al., 2012). We use the term "black carbon" when referring generally to the concept of "soot"type aerosol, while $\mathrm{rBC}$ is used when referring to quantities measured by the SP-AMS. In the SP-AMS, rBC and associated species are volatilized in an infrared laser beam $(1064 \mathrm{~nm})$ and are ionized using $70 \mathrm{eV}$ electron impact ionization followed by detection in a time-of-flight mass spectrometer (ToF-MS) operated in "V mode." For the majority of the study the SP-AMS was operated at 1 min time resolution alternating between bulk mass spectrum (MS), particle timeof-flight (pToF), and single particle modes. The SP-AMS was operated at high time resolution $(1 \mathrm{~Hz})$ in MS mode for a total of 5 days during the roadside study. SP-AMS data were analyzed using the Igor Pro based analysis tool PIKA (Seuper, 2010). The single particle categorization procedure and $k$-means clustering algorithm that were used to analyze the single particle data followed the description in Lee et al. (2015a). Positive matrix factorization (PMF) analysis of ensemble data was performed to identify the sources of $\mathrm{rBC}$ and organics and to speciate different types of organic species (i.e., oxygenated organic aerosol (OOA), biomass burning organic aerosol (BBOA), and hydrocarbon-like organic aerosol (HOA)), based on procedures described previously (Paatero and Tapper, 1994; Zhang et al., 2011; Ulbrich et al., 2009).

Without the tungsten vaporizer, direct calibrations of the ionization efficiency for $\mathrm{NH}_{4} \mathrm{NO}_{3}\left(\mathrm{IE}_{\mathrm{NO}_{3}}\right)$ are not possible. Therefore, size-selected $(300 \mathrm{~nm})$ Regal black (Regal 400R pigment, Cabot Corp.) particles were used to determine the mass-based ionization efficiency of $\mathrm{rBC}\left(\mathrm{mIE}_{\mathrm{rBC}}\right)$ (Onasch et al., 2012; Willis et al., 2014). The relative ionization efficiency for $\mathrm{rBC}\left(\mathrm{RIE}_{\mathrm{rBC}}=\mathrm{mIE} \mathrm{rBC}_{\mathrm{rB}} / \mathrm{mIE}_{\mathrm{NO}_{3}}\right)$ was $0.2 \pm 0.05$, as experimentally determined before removal of the tungsten vaporizer. Assuming that $\mathrm{RIE}_{\mathrm{rBC}}$ is constant, $\mathrm{IE}_{\mathrm{NO}_{3}}$ could be calculated based on known values of $\mathrm{mIE}_{\mathrm{rBC}}$ and $\mathrm{RIE}_{\mathrm{rBC}}$. The average $\mathrm{mIE}_{\mathrm{rBC}}$ was $189 \pm 20$ ions pg ${ }^{-1}$ in the roadside study. The calculated $\mathrm{IE}_{\mathrm{NO}_{3}}$ was then used with recommended relative ionization efficiencies to quantify other aerosol species associated with $\mathrm{rBC}$ (Jimenez et al., 2003). Collection efficiency for $\mathrm{rBC}$ particles was determined in the roadside study using beam width probe (BWP) measurements described in Willis et al. (2014). Ambient $\mathrm{rBC}$-containing particles had an average beam width $\sigma=0.46 \pm 0.03 \mathrm{~mm}$, which is close to, but wider than, that of $300 \mathrm{~nm}$ Regal black particles $(\sigma=0.40 \pm 0.08$ ) (Willis et al., 2014). Therefore, a collection efficiency (CE) of 0.6 was applied for absolute quantification of $\mathrm{rBC}$ and associated species. A time-varying collection efficiency was not possible with BWP measurements available here; the assumption of a constant $\mathrm{CE}$ over periods of local and long-range transport influence in this study provided a good linear correlation with photoacoustic soot spectrometer (PASS) absorption measurements (405 and $781 \mathrm{~nm}$ ) and SP-AMS rBC (Healy et al., 2015, Fig. 4). Note that the CE applied will not impact calculations of the mass fraction of $\mathrm{rBC}\left(\mathrm{mf}_{\mathrm{rBC}}\right)$. However, two additional uncertainties in SP-AMS measurements may affect calculation of $\mathrm{mf}_{\mathrm{rBC}}$. First, there are uncertainties in the recommended RIE for organic species evaporating from rBC in the SP-AMS of up to $\sim 50 \%$ (Lee et al., 2015a; Willis et al., 2014), which could cause an overestimation in the mass of coating material and a corresponding underestimation in $\mathrm{mf}_{\mathrm{rBC}}$. Second, it is possible for $\mathrm{rBC}$-containing particles to pass through the edges of the laser vaporizer, thus producing a heating effect sufficient to evaporate some fraction of the coating materials but not evaporate the $\mathrm{rBC}$ itself. This effect may also lead to an underestimation in $\mathrm{mf}_{\mathrm{rBC}}$. SPAMS CE and quantification are discussed in further detail in Supplement Sect. S1.

\subsection{Photoacoustic soot spectrometer}

A photoacoustic soot spectrometer (PASS-3, Droplet Measurement Techniques, Boulder, $\mathrm{CO}$ ) was used to measure aerosol absorption $\left(b_{\mathrm{abs}}\right)$ and scattering $\left(b_{\mathrm{abs}}\right)$ coefficients $\left(\mathrm{M} \mathrm{m}^{-1}\right)$ at 405 and $781 \mathrm{~nm}$. A $532 \mathrm{~nm}$ laser is not installed in this particular unit. The PASS determines aerosol absorption $\left(\mathrm{Mm}^{-1}\right)$ in a cavity which acts as an acoustic resonator. The absorption of incoming radiation heats the particles, which in turn heat the surrounding air in the cavity (Arnott et al., 1999). The aerosol-laden air thus expands, resulting in a pressure disturbance. By modulating the laser power at the resonance frequency of the cavity, the pressure disturbance is amplified and the resulting acoustic wave is measured using a microphone. Light scattering at both wavelengths is concurrently measured using reciprocal nephelometry (Moosmüller et al., 2009; Flowers et al., 2010; Chan et al., 2011). Scattering signals were not corrected for truncation; however, since mass-based particle size distributions at the roadside site generally peaked near or below $100 \mathrm{~nm}$ a negative bias in the scattering measurement is unlikely. Since a $532 \mathrm{~nm}$ laser was not present in this unit an $\mathrm{NO}_{2}$ calibration was not possible, and the instrument was calibrated using a propane soot generator (miniCAST, 6203A, Jing). PASS measurements of the bulk single scattering albedo at $405 \mathrm{~nm}$ (selected due to superior signal-to-noise ratio for scattering relative to the $781 \mathrm{~nm}$ channel) are used here only to illustrate differences in optical properties in vehicle plumes with varying composition. 


\subsection{Particle-resolved box model simulations}

We used the stochastic particle-resolved box model PartMCMOSAIC (Particle Monte Carlo - Model for Simulating Aerosol Interactions and Chemistry) (Riemer et al., 2009; Zaveri et al., 2008) to quantify the importance of the observed mixing state information for the calculation of cloud condensation nuclei $(\mathrm{CCN})$ and aerosol optical properties. PartMC-MOSAIC is suited for this task, as it explicitly tracks the composition of individual aerosol particles (in our case about $10^{5}$ particles) in a population of different particle types within a well-mixed computational volume. Particle emissions, dilution with the background, and Brownian coagulation are simulated stochastically with PartMC, by generating a realization of a Poisson process using weighted particles in the sense of DeVille et al. (2011) and an accelerated binned sampling strategy (Michelotti et al., 2013). Coupled to PartMC is the MOSAIC chemistry code, which simulates gas chemistry (Zaveri and Peters, 1999), particle-phase thermodynamics (Zaveri et al., 2005a, b), and dynamic gasparticle mass transfer (Zaveri et al., 2008) in a deterministic manner.

Here we compare two simulations that differ in the way the mixing state of the aerosol initial conditions and the aerosol emissions are prescribed. The setup of the particle-resolved simulations is similar to the urban plume scenarios in Riemer et al. (2009) and Zaveri et al. (2010). Common to both simulations are the following specifics. The number of computational particles used in the simulation is about $10^{5}$. The total simulation time is $24 \mathrm{~h}$, with a simulation start of 06:00 local standard time. The initial gas-phase concentrations are the same as in Zaveri et al. (2010). In contrast to Zaveri et al. (2010), we prescribe a constant mixing height $(400 \mathrm{~m})$, relative humidity $(70 \%)$, and temperature $(298.15 \mathrm{~K})$ to simplify the interpretation of the results. Since the entrainment of background aerosol can modify the aerosol mixing state substantially (Liu et al., 2011), we include constant dilution with the background at a rate of $1.5 \times 10^{-5} \mathrm{~s}^{-1}$. The background aerosol is non-absorbing and consists of ammonium sulfate mixed with biogenic secondary organic aerosol. This dilution rate corresponds to about $75 \%$ of the aerosol being replaced in a $24 \mathrm{~h}$ period, comparable to a diurnal mixing height increase of 500 to $2000 \mathrm{~m}$ (e.g., Liu et al., 2011), although imposed uniformly over the day for simplicity. We also reduced the gas-phase emissions by a factor of 2 compared to $\mathrm{Za}-$ veri et al. (2010) to create more moderately polluted conditions. The initial aerosol population was sampled from lognormal size distributions fitted from the measurement data, as shown in Table S1 in the Supplement. The derivation of model inputs from measurement data is described in Supplement Sect. S3.

To fully exploit the information supplied by the observations, we introduced a new method of sampling the aerosol composition for the aerosol initial conditions and emissions. We now allow for stochastic composition variation at each di- ameter, with a prescribed standard deviation around a mean value. The new composition-sampling method proceeds as follows. For each aerosol particle, the diameter is first sampled, and then the composition is sampled as a vector of mass fractions $\boldsymbol{w}=\left[w_{\mathrm{BC}}, w_{\mathrm{HOA}}\right]^{\top}$. Although we only sample two species for the simulations in this paper, we specify the sampling algorithm for any number of species. We use bold italic to denote vectors, so $\boldsymbol{m} \boldsymbol{f}$ is the mean mass fraction vector from Table S1 in the Supplement. We write $\boldsymbol{\Sigma}$ for the diagonal covariance matrix with diagonal entries $\left(\sigma_{i}\right)^{2}, \mathbf{1}$ for the vector of ones, and $\boldsymbol{x}^{\top}$ for the transpose of a vector $\boldsymbol{x}$. We sample the composition vector $\boldsymbol{w}$ from a multivariate normal distribution on the affine hyperplane of vectors that sum to 1 , truncated to the positive closed orthant (and thus to the probability or standard simplex). This is done as shown in Algorithm 1 using an accept-reject procedure.

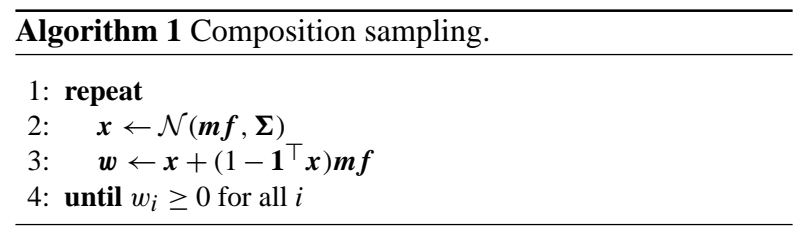

Algorithm 1 has five important properties, as follows. (1) It is clear that if the algorithm terminates then $\boldsymbol{w}$ lies in the positive closed orthant, so every species has a non-negative mass fraction. (2) The sum of the sampled mass fractions $\boldsymbol{w}$ is one, as can be seen from $\mathbf{1}^{\top} \boldsymbol{w}=\mathbf{1}^{\top} \boldsymbol{x}+\left(1-\mathbf{1}^{\top} \boldsymbol{x}\right) \mathbf{1}^{\top} \boldsymbol{m} \boldsymbol{f}=$ $\mathbf{1}^{\top} \boldsymbol{x}+1-\mathbf{1}^{\top} \boldsymbol{x}=1$, assuming that the mean mass fractions sum to one and so $\mathbf{1}^{\top} \boldsymbol{m} \boldsymbol{f}=1$. (3) The distribution of $\boldsymbol{w}$ is a truncated multivariate normal, which follows from the fact that $\boldsymbol{x}$ has a multivariate normal distribution, $\boldsymbol{w}$ is an affine function of $\boldsymbol{x}$, and the accept-reject procedure samples from the truncation of the per-iteration distribution. Note, however, that the resulting marginal distributions for each singlespecies mass fraction will not in general have mean and standard deviation given by $\boldsymbol{m} \boldsymbol{f}_{i}$ and $\sigma_{i}$, respectively. (4) Adding additional species with 0 mean mass fraction and 0 standard deviation will not change the distribution of the other sampled mass fractions, as the additional species will have 0 components in both $\boldsymbol{x}$ and $\boldsymbol{w}$ and will not alter the calculation of any other components. (5) Finally, the algorithm will terminate with probability 1 , under the conditions that the mean mass fractions sum to 1 and each $\sigma_{i}$ is non-negative and 0 only if the corresponding $\boldsymbol{m} \boldsymbol{f}_{i}$ is non-negative. This last property can be seen by first considering the set $A$ of $\boldsymbol{x}$ that will result in a $\boldsymbol{w}$ in the positive closed orthant, terminating the algorithm. This set $A$ is exactly the direct sum of the probability simplex with the span of $\{\boldsymbol{m} \boldsymbol{f}\}$, as can be seen by checking that $\boldsymbol{x}=\boldsymbol{p}+\alpha \boldsymbol{m} \boldsymbol{f}$ for $\boldsymbol{p}$ in the probability simplex and any scalar $\alpha$ results in $\boldsymbol{w}=\boldsymbol{p}$, so that the entire probability simplex is thus obtained from $A$. The conditions on $\boldsymbol{m} \boldsymbol{f}$ and the $\sigma_{i}$ imply that $\boldsymbol{x}$ has non-zero probability of lying in $A$, and hence the algorithm has non-zero probability of terminating on each iteration. Because each iteration is 

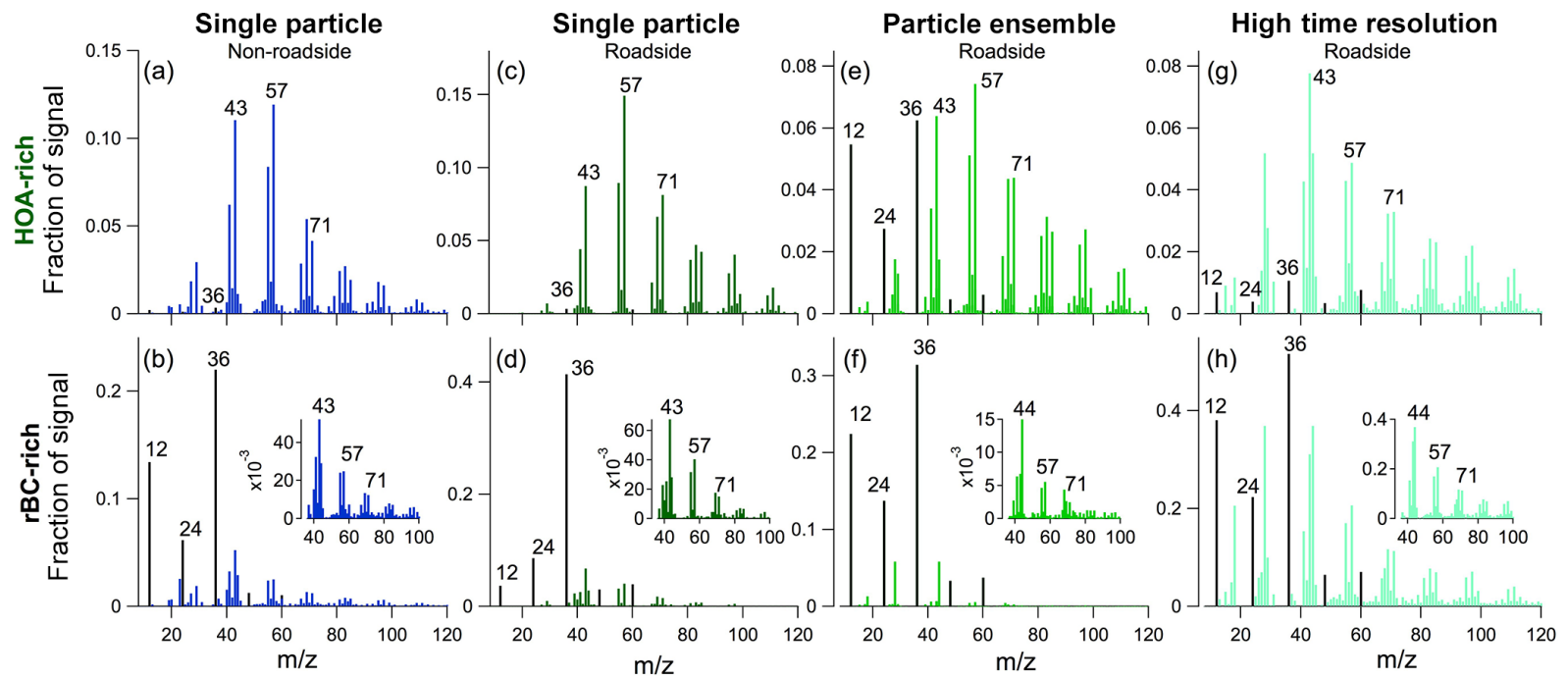

Figure 1. Unit mass resolution (UMR) spectra of HOA-rich (a) and rBC-rich (b) particle classes identified by $k$-means cluster analysis of single particle SP-AMS data acquired in the non-roadside environment. UMR spectra of HOA-rich (c) and rBC-rich (d) particle classes identified from single particle data in the roadside environment. High-resolution mass spectra of HOA-rich (e) and rBC-rich (f) PMF factors from ensemble SP-AMS data from the roadside study (i.e., for $\mathrm{rBC}$-containing particles only). Examples of UMR spectra collected at high time resolution during HOA-rich (g) and rBC-rich (h) plumes (corresponding time series are shown in Fig. 6) during the roadside study. Insets in the lower panels illustrate the UMR spectrum of organic species (without $\mathrm{CO}_{x}^{+}$fragments) in the $\mathrm{rBC}$-rich mass spectra. Black and coloured sticks represent the fragments of $\operatorname{rBC}\left(\mathrm{C}_{x}^{+}\right)$and organic species $\left(\mathrm{C}_{x} \mathrm{H}_{y}^{+}, \mathrm{C}_{x} \mathrm{H}_{y} \mathrm{O}_{w}^{+}\right)$, respectively.

an independent and identically distributed Bernoulli trial, the algorithm thus terminates with probability 1 .

The two simulations differ in the assigned mixing state of the initial aerosol populations and the aerosol emissions. For the measurement-constrained case we distinguish between rBC-rich and HOA-rich particle classes, as the observations indicate. Both classes consist of two modes, which amounts to four modes in total, as listed in Table S1 in the Supplement. Note that the modes BC1 and HOA1 have the same geometric mean diameter and geometric standard deviation, but they differ in their abundance and their emission rate, respectively. The same applies to modes BC2 and HOA2. This specific choice is guided by the observations as shown in Table S1.

For the uniform case only two modes are prescribed, with the same geometric mean diameter and standard deviation as modes $\mathrm{BC} 1 / \mathrm{HOA} 1$ and $\mathrm{BC} 2 / \mathrm{HOA} 2$, respectively (Table $\mathrm{S} 2$ ). The mass fractions of $\mathrm{BC}$ and HOA in these two modes are identical, and they are equal to the mass fractions of the bulk concentrations for the measurement constrained case. Hence the uniform case represents conditions for which the bulk mass concentrations and the size distribution are the same as for the measurement-constrained case, but for which the detailed mixing state information is not available. A comparison of the two cases therefore quantifies the importance of mixing state information at emission for properties of interest, such as optical properties and $\mathrm{CCN}$ activation properties.

Figure S10 shows the temporal evolution of the bulk aerosol species over the course of the $24 \mathrm{~h}$ simulation. The primary species black carbon and organic carbon increase initially owing to emissions and then decrease after emissions are discontinued at $t=12 \mathrm{~h}$ as a result of dilution with the background. The model simulations also show the production of inorganic and organic secondary aerosol species, which condense on the primary particles, continuously modifying the composition of each particle in the aerosol population. Not shown in this figure is the aerosol water content. While the particles start out dry, they take up water around $t=6 \mathrm{~h}$ when nitrate formation begins.

We calculate the optical properties for ambient conditions (including aerosol water content) at a wavelength of $550 \mathrm{~nm}$ and the critical supersaturations of each particle in a postprocessing step according to Zaveri et al. (2010). For the optical properties we assume spherical particles with a "coreand-shell" configuration in which $\mathrm{BC}$ forms the particle core and the other substances compose the shell. We then use Mie calculations (Ackerman and Toon, 1981) to determine the extinction and scattering cross sections for each particle in the population. From these values, the volume extinction, scattering, and absorption coefficients can be reconstructed. Note that we assume all primary and secondary organic substances to be non-absorbing; hence we do not consider any effects due to brown carbon.

To determine the critical supersaturations, we employ $\kappa$ Köhler theory (see Zaveri et al., 2010 for details). Based on the critical supersaturation values of each particle in the population, we construct CCN spectra, as shown in Fig. S11 for different times throughout the simulation. As the simulation 

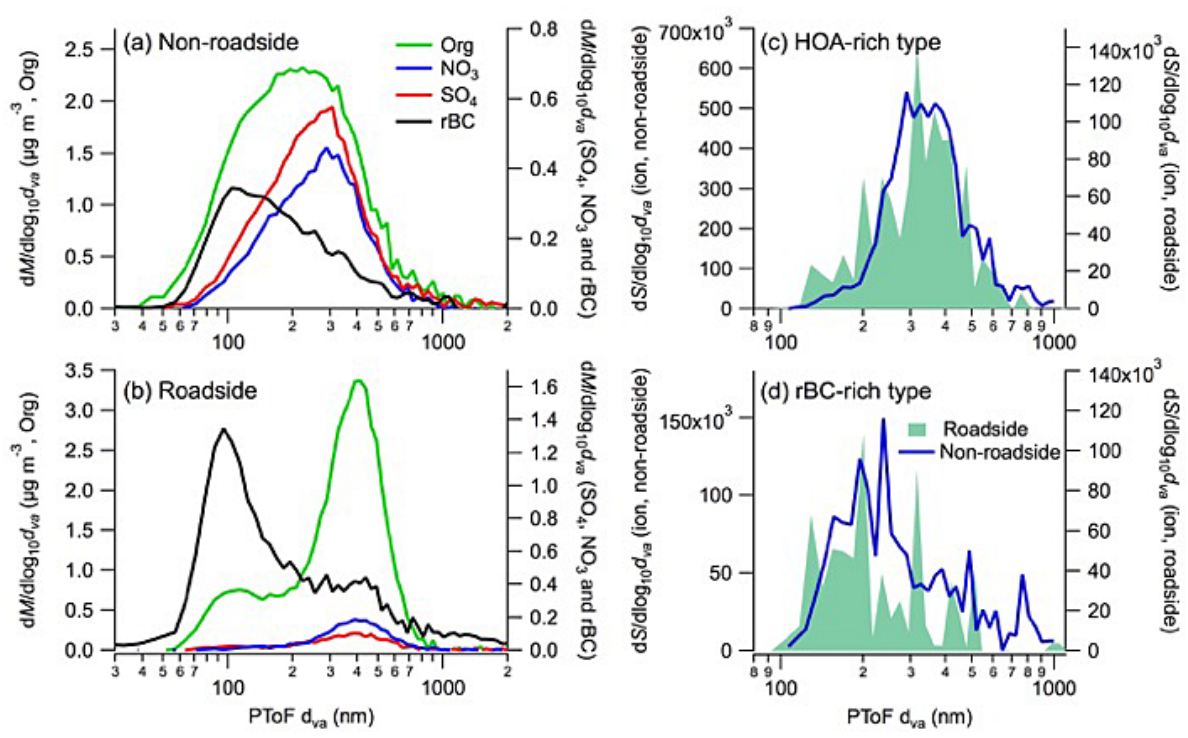

Figure 2. Particle size distributions from the non-roadside and roadside studies: (a) mass-based ensemble size distribution of refractory black carbon (rBC, black), organic species (Org, green), sulphate $\left(\mathrm{SO}_{4}\right.$, red), and nitrate $\left(\mathrm{NO}_{3}\right.$, blue) for the non-roadside study; (b) mass-based ensemble size distribution from the roadside study; (c) ion-signal-based single particle size distributions for HOA-rich particle classes from the roadside (filled green) and non-roadside (blue) studies; (d) ion-signal-based single particle size distributions for $\mathrm{rBC}$-rich particle classes from the roadside (filled green) and non-roadside (blue) studies. The SP-AMS measured rBC-containing particles only during the roadside study, while both rBC-containing and non-rBC-containing particles were measured in the non-roadside study.

progresses, the $\mathrm{CCN} / \mathrm{CN}$ fraction at low values of critical supersaturation increases, since the particles become more hygroscopic due to the condensation of secondary aerosol material. Since both primary organic carbon $(\kappa=0.001)$ and black carbon $(\kappa=0)$ are model species with similar and low hygroscopicity parameters, the differences between the uniform case and the measurement-constrained case are expected to be small, and the two CCN spectra are almost indistinguishable, as we will show in Sect. 3.3.

\section{Results and discussion}

\subsection{Two classes of fresh black carbon particles}

Based on single particle SP-AMS measurements in both roadside and non-roadside studies, we identified two types of particles originating from vehicle exhaust, which are primarily composed of $\mathrm{rBC}$ and hydrocarbon-like organic aerosol (Fig. 1a-d). One type is dominated by HOA mass (referred to as the "HOA-rich" particle class) and the other is dominated by $\mathrm{rBC}$ ("rBC-rich" particle class). The mass spectra of HOA-rich particles (Fig. 1a and c) exhibit fragmentation patterns associated with hydrocarbon structures (e.g., $\left.m / z 43\left(\mathrm{C}_{3} \mathrm{H}_{7}^{+}\right), 57\left(\mathrm{C}_{4} \mathrm{H}_{9}^{+}\right), 71\left(\mathrm{C}_{5} \mathrm{H}_{11}^{+}\right)\right)$and are consistent with previous aerosol mass spectrometer observations of gasoline/diesel vehicle exhaust and unburned lubricating oil (Massoli et al., 2012; Canagaratna et al., 2004; Mohr et al., 2009). In conjunction with differences in mass spec- tra, clear differences in particle size distributions (Fig. 2c and d) demonstrate that the division of traffic-related rBCcontaining particles into HOA-rich and $\mathrm{rBC}$-rich classes is physically meaningful.

The average mass fractions of $\mathrm{rBC}\left(\mathrm{mf}_{\mathrm{rBC}}\right)$ in HOA-rich particles during the non-roadside and roadside studies are low: 0.03 and 0.05 , respectively. The narrow distribution of $\mathrm{mf}_{\mathrm{rBC}}$ (Fig. 3a) suggests that most of the HOA-rich particles are either mixed with a small amount of $\mathrm{rBC}$ or do not contain detectable $\mathrm{rBC}$ mass, while a very small number of particles contain larger $\mathrm{mf}_{\mathrm{rBC}}$ (Fig. 3, split axis). Mass spectra of $\mathrm{rBC}$-rich particles are dominated by $\mathrm{C}_{x}^{+}$fragments (i.e., $m / z 12,24,36,48$, and 60 in Fig. $1 \mathrm{~b}$ and d) arising from black carbon. Smaller signals associated with HOA-like material in these particles are similar to the primary organic materials derived from diesel engine exhaust observed in laboratory studies (Sage et al., 2008). In contrast to the HOA-rich particles, Fig. $3 \mathrm{c}$ illustrates a wider range of $\mathrm{mf}_{\mathrm{rBC}}$ values in rBC-rich particles. In the non-roadside and roadside environments the average $\mathrm{mf}_{\mathrm{rBC}}$ values $( \pm 1$ standard deviation) in this particle class are $0.72( \pm 0.18)$ and $0.86( \pm 0.14)$, respectively, highlighting the possibility that condensation and/or coagulation of HOA material on $\mathrm{rBC}$ particles might occur within a short time of emission.

The mass fraction of $\mathrm{rBC}$ derived from SP-AMS measurements may be best regarded as a lower limit. For the reasons detailed in Sect. 2.1.2, including the potential for incomplete vaporization and uncertainty in SP-AMS sensitivity to $\mathrm{rBC}$ coating materials, $\mathrm{mf}_{\mathrm{rBC}}$ values presented here may be un- 

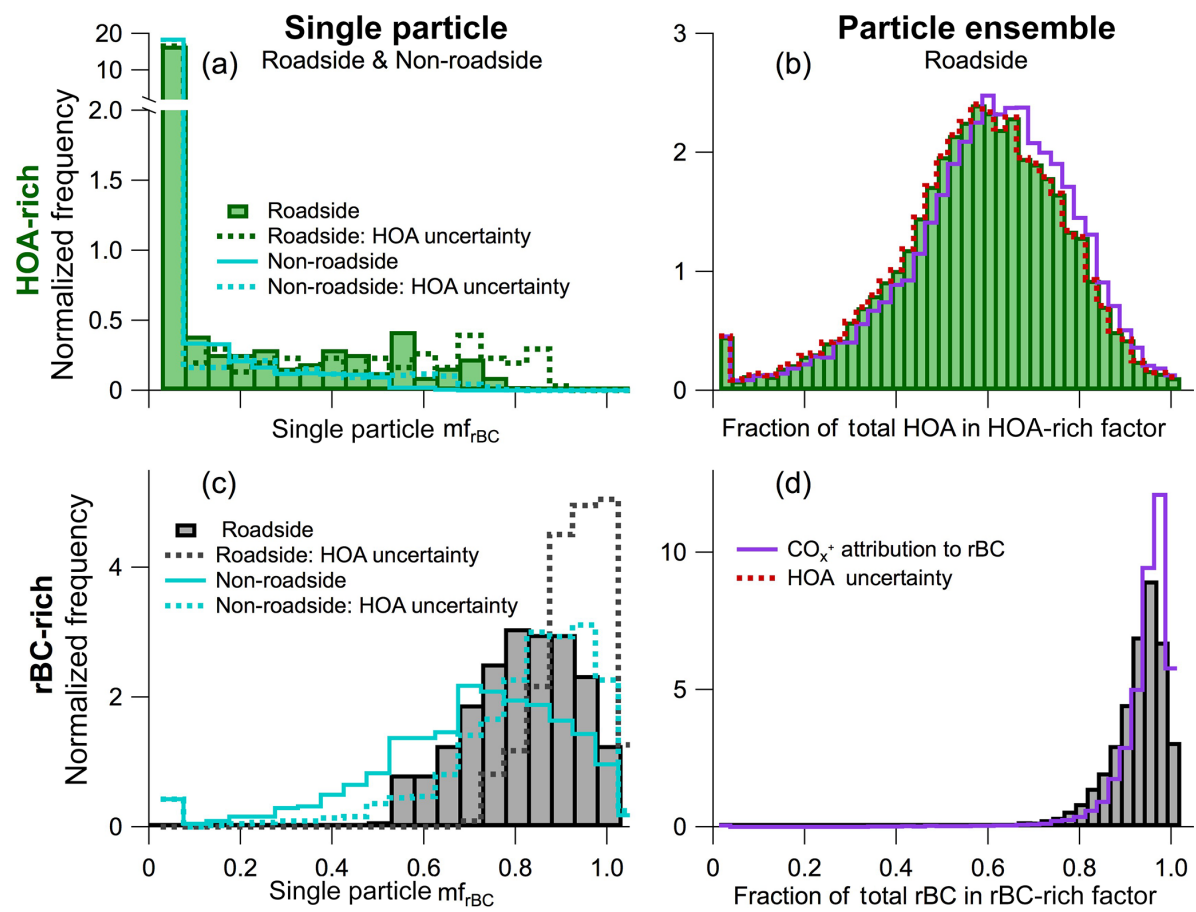

Figure 3. (a, c) The distribution of $\mathrm{mf}_{\mathrm{rBC}}$ (presented as a normalized histogram) in the HOA-rich (a) and $\mathrm{rBC}$-rich (c) particle classes in roadside (green and black) and non-roadside (blue) environments. Bars and solid lines represent $\mathrm{mf}_{\mathrm{rBC}}$ calculated from $\mathrm{rBC}_{\mathrm{fragments}}$ (i.e., $\mathrm{C}_{x}^{+}$) and dashed lines represent the impact of a $50 \%$ decrease in HOA mass loading to illustrate the impact of uncertainty in HOA quantification. (b, d) Normalized histograms of $\mathrm{mf}_{\mathrm{Org}}$ in the HOA-rich factor (b) and $\mathrm{mf}_{\mathrm{rBC}}$ in the $\mathrm{rBC}$-rich factor (d), i.e., frequency distribution showing the fraction of total $\mathrm{rBC}(\mathrm{HOA})$ contributed by the $\mathrm{rBC}$-rich (HOA-rich) factor. Bars represent $\mathrm{mf}_{\mathrm{rBC}}$ calculated by $\mathrm{rBC}$ fragments (i.e., $\mathrm{C}_{x}^{+}$), whereas solid purple lines represent the $\mathrm{mf}_{\mathrm{rBC}}$ calculated including both $\mathrm{CO}_{x}^{+}$and $\mathrm{C}_{x}^{+}$fragments, yielding similar results (see Sect. S1). Red dashed lines represent the impact of a $50 \%$ decrease in HOA mass loading to illustrate the impact of uncertainty in HOA quantification.

derestimated. A $50 \%$ overestimation in the mass of HOA would increase $\mathrm{mf}_{\mathrm{rBC}}$ in $\mathrm{rBC}$-rich particles to $0.85( \pm 0.16)$ and $0.92( \pm 0.10)$ in the non-roadside and roadside studies, respectively (Fig. 3c, dashed lines). In addition to these uncertainties, in the roadside study only rBC-containing particles are detected by the SP-AMS, while in the non-roadside study it is possible that the HOA-rich class includes HOA particles that do not contain rBC (i.e., "externally mixed" HOA).

\subsubsection{Differences in particle coating thickness}

With single particle detection capability, SP-AMS observations can be used to quantify the thickness of non-refractory particulate matter on individual $\mathrm{rBC}$-containing particles. This calculation focuses only on determining the thickness of HOA coating derived from traffic emissions; however, OOA, BBOA, and secondary inorganic species were mixed with $\mathrm{rBC}$ in more aged accumulation mode particles in these urban studies and a similar calculation could be carried out for these particle classes (Lee et al., 2015a, b).

We assume a core-shell structure in order to determine the thickness of HOA coating on fresh $\mathrm{rBC}$-containing particles.
In addition, we assume a spherical $\mathrm{rBC}$ core, a uniform thickness of coating, and an HOA density of $0.9 \mathrm{~g} \mathrm{~cm}^{-3}$. To simulate the effect of the fractal structure of ambient $\mathrm{rBC}$, the effective density of $\mathrm{rBC}\left(\rho_{\mathrm{eff}, \mathrm{rBC}}\right)$ was varied between 0.3 and $1.3 \mathrm{~g} \mathrm{~cm}^{-3}$, values that have been observed for laboratory soot standards and engine exhaust (Maricq and Ning, 2004; Gysel et al., 2011). Figure 4 presents the two-dimensional histograms $\left(\mathrm{mf}_{\mathrm{rBC}}\right.$ vs. particle aerodynamic diameter, $\left.d_{\mathrm{va}}\right)$ of rBC-rich and HOA-rich particles identified by cluster analysis in the two urban studies, with calculated coating thickness curves overlaid for comparison (dashed lines). The coating thickness is relatively insensitive to variations in $\rho_{\mathrm{eff}, \mathrm{rBC}}$ (Fig. 4, dashed lines).

These observations demonstrate that $\mathrm{rBC}$-rich particles are only very thinly coated with HOA material, as compared to HOA-rich particles that have only very small $\mathrm{rBC}$ inclusions (Fig. 4). Here we use two specific examples to illustrate that the coating thickness on HOA-rich and $\mathrm{rBC}$-rich particles can vary significantly. First, a $200 \mathrm{~nm}\left(d_{\mathrm{va}}\right) \mathrm{rBC}$-rich particle (i.e., physical particle diameter $\sim 245 \mathrm{~nm}$, assuming $\rho_{\mathrm{eff}, \mathrm{rBC}}=0.8 \mathrm{~g} \mathrm{~cm}^{-3}$ ) with $72-86 \% \mathrm{rBC}$ by mass (the average $\mathrm{mf}_{\mathrm{rBC}}$ of $\mathrm{rBC}$-rich particles) would be covered by a 5-11 nm HOA coating. Second, a $300 \mathrm{~nm}\left(d_{\mathrm{va}}\right)$ HOA-rich 

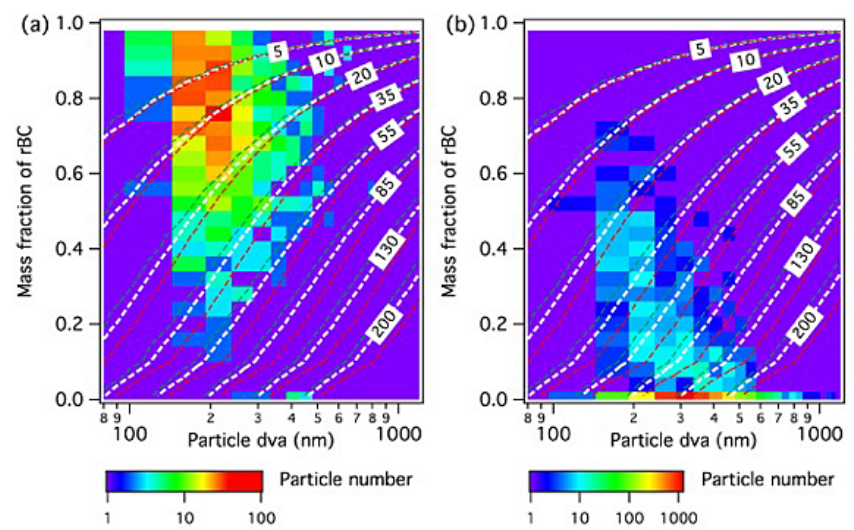

Figure 4. Two-dimensional histograms $\left(\mathrm{mf}_{\mathrm{rBC}}\right.$ vs. particle aerodynamic diameter) of rBC-rich (a) and HOA-rich (b) particle classes. The colour scale represents the number of particles in each particle class. The dashed lines represent the physical thickness (nm) of organic coating on rBC-containing particles determined by modelling the particles as a core-shell structure. Note that the $d_{\mathrm{va}}$ of model outputs are calculated by the physical diameter $\left(d_{\mathrm{p}}\right)$ and the density $\left(\rho_{\mathrm{p}}\right)$ of particles (i.e., $d_{\mathrm{va}}=d_{\mathrm{p}} \cdot \rho_{\mathrm{p}}$, where $\rho_{\mathrm{p}}$ is the linear combination of mass-weighted HOA and $\mathrm{rBC}$ density). To examine the potential effect of fractal structure of ambient $\mathrm{rBC}$ particles on predicted coating thickness, the effective density of $\mathrm{rBC}$ was varied (green: $0.3 \mathrm{~g} \mathrm{~cm}^{-3}$; white: $0.8 \mathrm{~g} \mathrm{~cm}^{-3}$; red: $1.3 \mathrm{~g} \mathrm{~cm}^{-3}$ ).

particle (i.e., physical particle diameter $\sim 335 \mathrm{~nm}$, assuming $\left.\rho_{\mathrm{eff}, \mathrm{rBC}}=0.8 \mathrm{~g} \mathrm{~cm}^{-3}\right)$ that co-exists with a small amount of $\mathrm{rBC}$ mass $\left(3-5 \%\right.$ by mass, the average $\mathrm{mf}_{\mathrm{rBC}}$ of HOA-rich particles) has an $\mathrm{rBC}$ core size of $108-119 \mathrm{~nm}$ and a thick HOA coating $(108-113 \mathrm{~nm})$.

\subsection{Black carbon mass is dominated by $\mathrm{BC}$-rich particles}

Single particle measurements provide direct insight into mixing state at an individual particle level; however, single particle detection has an inherent bias towards large particle sizes because light scattering triggers particle detection (Lee et al., 2015a; Cross et al., 2009; Freutel et al., 2013; S. Liu et al., 2013). Ensemble size distributions of $\mathrm{rBC}$ peaked at $\sim 100 \mathrm{~nm}$ in both roadside and non-roadside studies indicating that fresh $\mathrm{rBC}$-containing particles emitted from vehicle exhaust are small (Fig. 2a and b). Smaller rBC-containing particles fall below the lower size limit of single particle detection (Fig. 2c and d). Therefore, single particle observations do not necessarily quantify mixing state at the population level. To provide a complementary view of $\mathrm{rBC}$ mixing state we turn to ensemble measurements from the roadside study where only $\mathrm{rBC}$-containing particles were detected in the SP-AMS. Ensemble measurements better represent mixing state on a population basis compared to single particle observations, because they cover a wider range of particle size (i.e., $80-1000 \mathrm{~nm}$ vacuum aerodynamic diameter, $d_{\mathrm{va}}$ ).

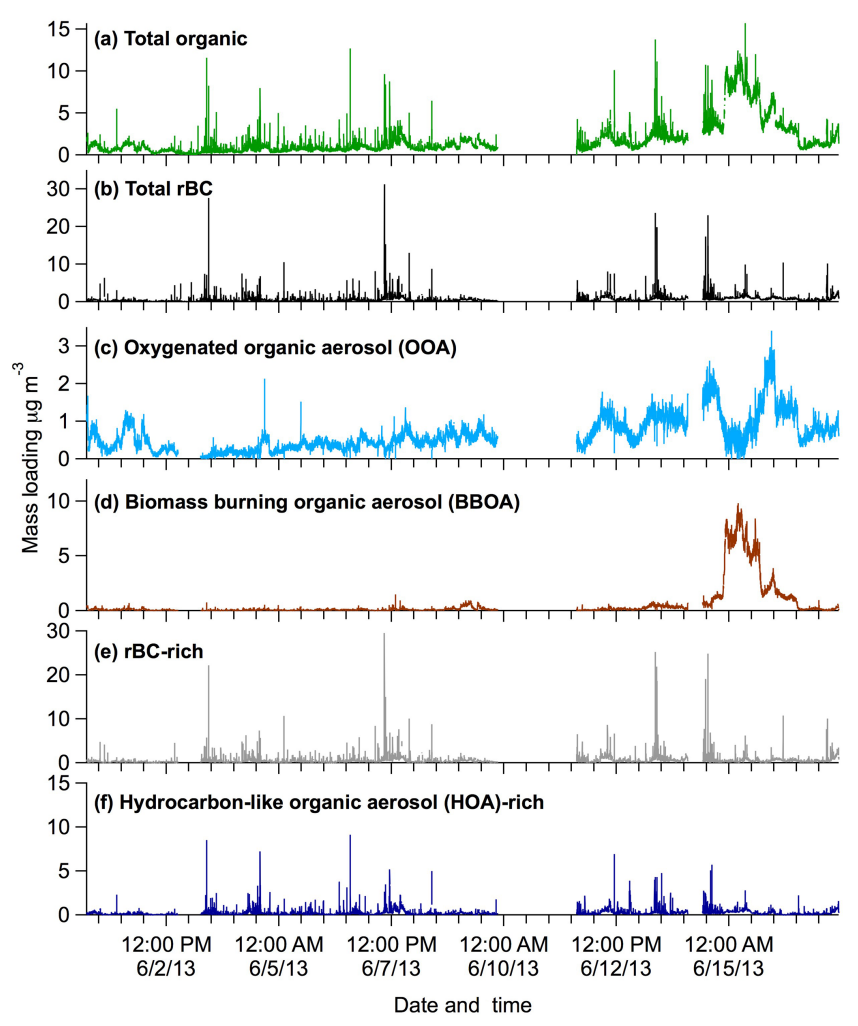

Figure 5. Time series of (a) ensemble organic aerosol and (b) refractory black carbon mass loadings during the roadside study. Positive matrix factorization (PMF) results for ensemble data (c-f): (c) regionally sourced $\mathrm{rBC}$ mixed with oxygenated organic aerosol, (d) biomass-burning organic aerosol mixed with $\mathrm{rBC}$, and trafficrelated $\mathrm{rBC}$ in an $\mathrm{rBC}$-rich and HOA-rich factor (e) and (f). Mass spectra of all PMF factors are shown in Fig. S1.

By measuring very close to a busy road, ensemble SPAMS observations of $\mathrm{rBC}$ and organic aerosol enabled the analysis of more than 100 vehicle exhaust plumes over the course of the roadside study (Fig. 5a and b). PMF (Zhang et al., 2011; Ulbrich et al., 2009) indicates three major sources of rBC-containing aerosol in the roadside environment: transported BBOA, regional background (OOA), and traffic emissions comprised of two PMF factors (HOA-rich and $\mathrm{rBC}$-rich factors; Fig. 5c-f). Inorganic species evident in the bulk aerosol size distributions (Fig. 2a and b) are largely associated with OOA and BBOA factors, while the trafficrelated factors contain the majority of $\mathrm{rBC}$ and HOA (Lee et al., 2015a, b). Mass spectra of all four PMF factors and a discussion of selection of the number of factors are presented in Supplement Sect. 2. Not previously observed with an AMS, the HOA-rich and $\mathrm{rBC}$-rich factors represent two types of vehicle exhaust plumes with different amounts of $\mathrm{rBC}$ and HOA (Fig. 1e and f). The $\mathrm{mf}_{\mathrm{rBC}}$ of HOA-rich and $\mathrm{rBC}$-rich factors are 0.16 and 0.75 , respectively. High-time-resolution SP-AMS measurements (Fig. 6) also demonstrated varying organic and $\mathrm{rBC}$ levels in vehicle plumes (Fig. $1 \mathrm{~g}$ and $\mathrm{h}$ ), 

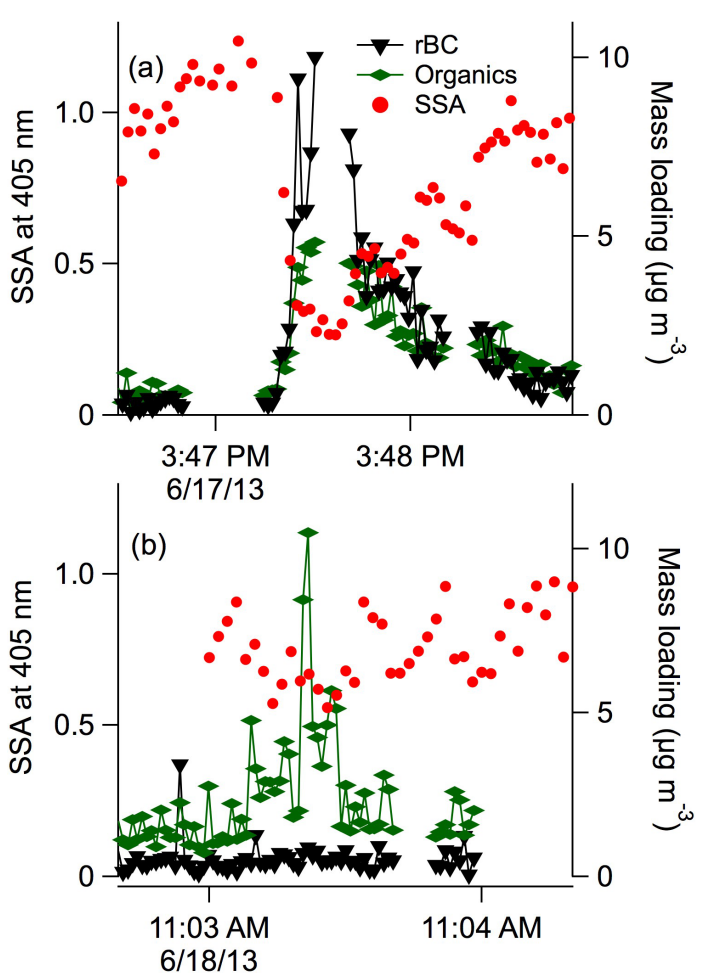

Date and time

Figure 6. Examples of rBC-dominated (a) and organicdominated (b) plumes observed using the SP-AMS with high-time-resolution $(1 \mathrm{~Hz})$ sampling, with measurements of single scattering albedo (SSA) at $405 \mathrm{~nm}$ from a photoacoustic soot spectrometer (PASS-3). Gaps in SP-AMS data correspond to periods used for the subtraction of gas-phase contributions from particle signals. Mass spectra shown in Fig. $1 \mathrm{~g}$ and $\mathrm{h}$ correspond to plumes in (b) and (a), respectively.

with corresponding differences in optical properties (SSA at $405 \mathrm{~nm}$ ) indicating that $\mathrm{rBC}$-rich plumes were more highly absorbing. The origin of different plume types at this site has been characterized through long-term measurements and is related to a variety of engine types, operating conditions, and pollution control features (Wang et al., 2015).

Mass spectra of HOA-rich and $\mathrm{rBC}$-rich PMF factors (Fig. 1e and f) are strikingly similar to the mass spectra of HOA-rich and $\mathrm{rBC}$-rich particle classes identified in the single particle measurements (Fig. 1c and d), validating the division of traffic emissions into the two factors observed here. The single particle and ensemble mass spectra show some differences. First, the HOA-rich factor has a larger rBC content compared to the HOA-rich particle class; second, the rBC-rich factor contains higher $\mathrm{CO}^{+}$and $\mathrm{CO}_{2}^{+}$signals compared to the rBC-rich particle class (inserts of Figs. 1d, e, and $\mathrm{f})$. The latter difference arises because highly oxygenated organic fragments $\left(\mathrm{m} / z 28\left(\mathrm{CO}^{+}\right)\right.$and $\left.44\left(\mathrm{CO}_{2}^{+}\right)\right)$were excluded in the single particle analysis due to interference of air signals in unit mass resolution spectra (Lee et al., 2015a).
Differences in $\mathrm{mf}_{\mathrm{rBC}}$ between single particle and ensemble measurements, especially for HOA-rich particles that contain a small amount of $\mathrm{rBC}$, could be due to the probability of $\mathrm{rBC}$ detection in a single particle such that single particle $\mathrm{mf}_{\mathrm{rBC}}$ may be underestimated relative to ensemble $\mathrm{mf}_{\mathrm{rBC}}$ Lee et al. (2015a).

With support of direct measurements of single particle mixing state, this work presents the first interpretation of ensemble AMS results in terms of $\mathrm{rBC}$ and $\mathrm{HOA}$ mixing state. Using the intensity of the two traffic-related factors in plumes (Fig. 5e and $\mathrm{f}$ ), we estimate that $\mathrm{rBC}$-rich particles account for $\sim 90 \%$ of the observed total traffic-related $\mathrm{rBC}$ mass (Fig. 3d). In a similar manner, we estimate that $\sim 60 \%$ of the total HOA mass is due to HOA-rich particles (Fig. 3b). Purple dashed lines shown in Fig. $3 \mathrm{~b}$ and d represent the inclusion of all $\mathrm{CO}_{x}^{+}$fragments (due to surface functionality of ambient rBC, Corbin et al., 2014) in the calculation of rBC mass (see Supplement Sect. S1), providing similar results. Dashed lines in Fig. 3a, b, and c represent the effect of a $50 \%$ overestimation of HOA mass (see Sect. S1), again providing similar results.

\subsection{Black carbon mixing state at emission impacts modelled optical properties}

These novel single particle and ensemble observations of $\mathrm{rBC}$ mixing state were used to initialize the particle-resolved aerosol box model PartMC-MOSAIC (see Sect. 2.3) (Zaveri et al., 2008; Riemer et al., 2009), which simulates the evolution of aerosol due to condensation and coagulation in an idealized urban setting. As described in Sect. 2.3, we simulate two cases to isolate the impact of mixing state of $\mathrm{rBC}$ emissions on aerosol properties: first, a uniform mixing state case in which all particles are assigned identical composition at emission (measured average $\mathrm{mf}_{\mathrm{rBC}}$ ); second, a measurementconstrained mixing state case where $\mathrm{mf}_{\mathrm{rBC}}$ is prescribed directly from our mixing state observations. The evolution of dry $\mathrm{mf}_{\mathrm{rBC}}$ over a $24 \mathrm{~h}$ period is illustrated in Fig. $7 \mathrm{a}$ and $\mathrm{b}$ for the two cases. As ageing proceeds $\mathrm{mf}_{\mathrm{rBC}}$ shifts to lower values, but in the uniform initial composition case no particles ever have $\mathrm{mf}_{\mathrm{rBC}}$ larger than $\sim 45 \%$. Note that the bulk aerosol composition and number size distributions are identical in the two cases (Fig. S10), and any differences in optical properties arise only due to the distribution of aerosol components amongst the particles.

Optical properties are determined for each particle in the population using Mie calculations and assuming a coreshell structure. We acknowledge that the underlying assumptions of Mie calculations may not be appropriate for rBCcontaining aerosol in the real atmosphere (e.g., Adachi et al., 2011; Scarnato et al., 2013), which is often not spherical and may not exhibit a core-shell configuration (e.g., China et al., 2015). In particular, the enhancement of rBC absorption due to non-absorbing coatings may be overestimated (Cappa et al., 2012; Healy et al., 2015), except in situations 

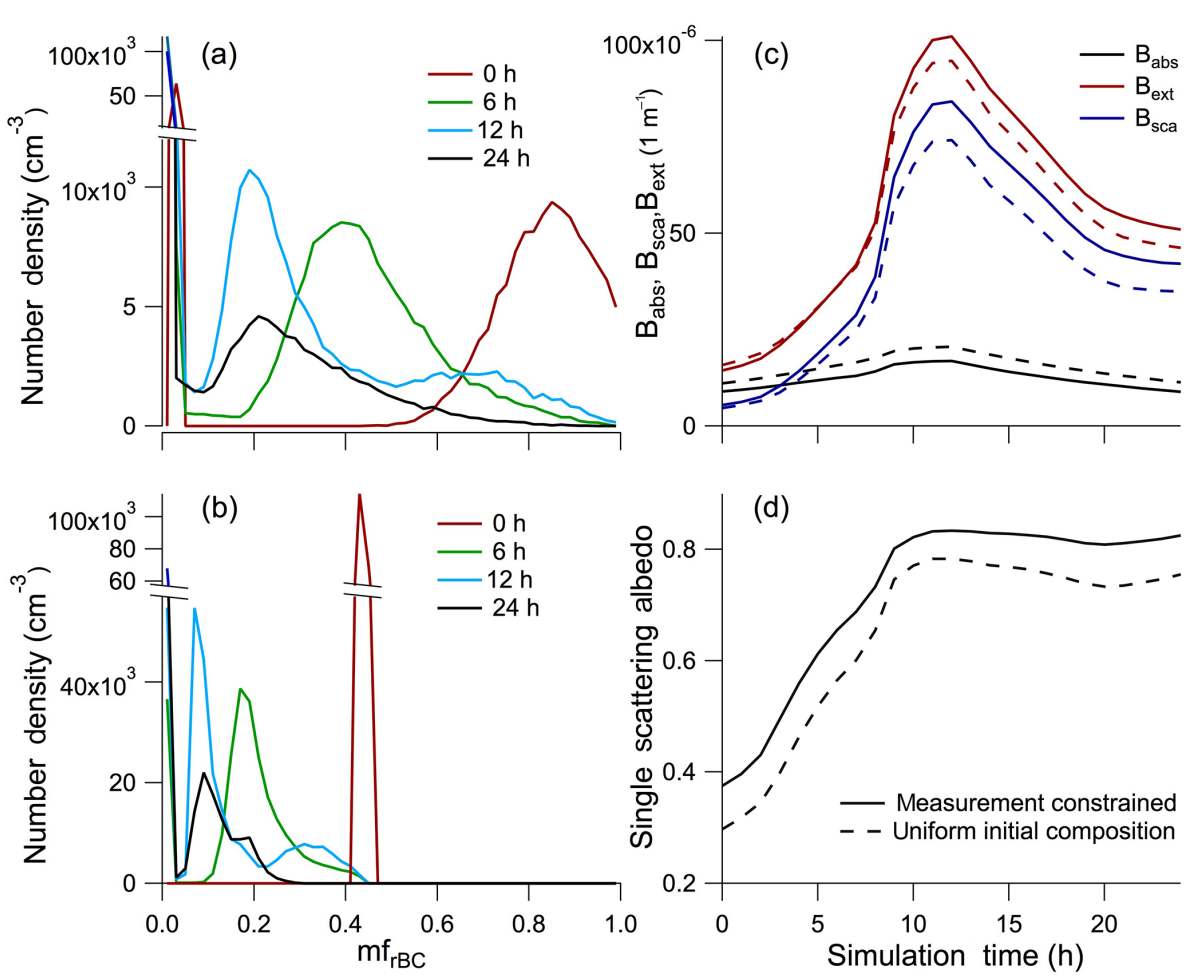

Figure 7. Evolution of dry $\mathrm{mf}_{\mathrm{rBC}}$ for the measurement-constrained (a) and uniform initial (b) mixing state cases. See Sects. 2 and $\mathrm{S} 3$ for a description of the model input parameters. Evolution of volume absorption $\left(B_{\text {abs }}\right)$, scattering $\left(B_{\text {scat }}\right)$, and extinction $\left(B_{\text {ext }}\right)$ coefficients at $550 \mathrm{~nm}$ (c) and single scattering albedo (SSA) at $550 \mathrm{~nm}$ over the $24 \mathrm{~h}$ simulation period (d) for measurement constrained (solid lines) and uniform initial mixing state (dashed lines) cases.

where $\mathrm{rBC}$ sources and ageing promote extensive coating (Liu et al., 2015; China et al., 2015). However, Mie calculations are commonly applied in regional and global models (Chung and Seinfeld, 2005; Zhao et al., 2013; Fast et al., 2006) to estimate optical properties, and we therefore include this comparison to illustrate the sensitivity to mixing state.

Consistent with previous studies (e.g., Zaveri et al., 2010; Matsui et al., 2013), we observe a difference in volume absorption and scattering coefficients ( $B_{\text {abs }}$ and $B_{\text {scat }}$, Fig. 7c) and a resulting increase of 0.1 in SSA from the uniform mixing state to the measurement-constrained case that is present during the emission period in the simulation and, notably, persists throughout ageing (Fig. 7d). Note that a direct comparison between measured and modelled SSA is not valid since we measure SSA of the bulk aerosol population and model it only for a subset of this population (i.e., the rBCcontaining particles). No significant differences in calculated cloud condensation nuclei activity were observed in these simulations (Fig. S11), owing to the very similar hygroscopicity of $\mathrm{rBC}$ and HOA species. Calculations of aerosol DRF are very sensitive to changes in SSA (McComiskey et al., 2008) (e.g., uncertainties in SSA on the order of only 0.02 can result in a DRF uncertainty of $1 \mathrm{~W} \mathrm{~m}^{-2}$ for a particular particle type; Chin et al., 2009), illustrating the importance of accurately measuring and simulating mixing state for calculating climatologically relevant aerosol properties.

\section{Conclusions}

We present mass-based measurements of the mixing state of BC-containing aerosol, using a soot-particle aerosol mass spectrometer, from traffic emissions in an urban environment. Observations from single particle mass spectrometry indicate that $\mathrm{rBC}$ co-exists with HOA in two distinct particle types: those containing a larger mass fraction of $\mathrm{rBC}$, and those containing a larger mass fraction of HOA. Source apportionment of ensemble mass spectral observations using positive matrix factorization also indicates two types of rBC-containing aerosol related to traffic: rBC-rich and HOArich aerosol, validated by single particle observations. Ensemble measurements expand the particle size range over which mixing state can be investigated, providing a better insight into the mixing state of the particle population and indicating that approximately $90 \%$ of $\mathrm{rBC}$ mass resides in rBC-rich particles. These measurements were used to drive the particle-resolved aerosol box model, PartMC-MOSAIC. Our results indicate an increase in SSA of $\sim 0.1$ when mixing state at the point of emission is treated accurately in the model compared to the assumption of uniform mixing state. 
The approach described here for quantitative assessment of black carbon mixing state from traffic can also be used to assess mixing state from other sources and to explore the evolution of mixing state during atmospheric processing. Such measurements will be crucial to drive accurate model assessment of black carbon climate impacts on a broader scale.

\section{The Supplement related to this article is available online at doi:10.5194/acp-16-4693-2016-supplement.}

Acknowledgements. This work was financially supported by Natural Sciences and Engineering Research Council (NSERC) of Canada, Environment Canada, the Canada Foundation for Innovation, and the Marie Curie Action FP7-PEOPLE-IOF-2011 (project CHEMBC, no. 299755). N. Riemer and M. West acknowledge funding from the Department of Energy under grant DOE DE-SC0011771.

Edited by: H. Su

\section{References}

Ackerman, T. and Toon, O.: Absorption of visible radiation in atmospheres containing mixtures of absorbing and nonabsorbing particles, Appl. Opt., 20, 3661-3668, doi:10.1364/AO.20.003661, 1981.

Adachi, K. and Buseck, P. R.: Changes of ns-soot mixing states and shapes in an urban area during CalNex, J. Geophys. Res.-Atmos., 118, 3723-3730, 2013.

Adachi, K., Freney, E. J., and Buseck, P. R.: Shapes of internally mixed hygroscopic aerosol particles after deliquescence, and their effect on light scattering, Geophys. Res. Lett., 38, L13804, doi:10.1029/2011GL047540, 113804, 2011.

Adachi, K., Zaizen, Y., Kajino, M., and Igarashi, Y.: Mixing state of regionally transported soot particles and the coating effect on their size and shape at a mountain site in Japan, J. Geophys. Res.Atmos., 119, 5386-5396, doi:10.1002/2013JD020880, 2014.

Arnott, W. P., Moosmüller, H., Rogers, C. F., Jin, T., and Bruch, R.: Photoacoustic spectrometer for measuring light absorption by aerosol: instrument description, Atmos. Environ., 33, 2845 2852, doi:10.1016/S1352-2310(98)00361-6, 1999.

Bond, T. C., Doherty, S. J., Fahey, D. W., Forster, P. M., Berntsen, T., DeAngelo, B. J., Flanner, M. G., Ghan, S., Kärcher, B., Koch, D., Kinne, S., Kondo, Y., Quinn, P. K., Sarofim, M. C., Schultz, M. G., Schulz, M., Venkataraman, C., Zhang, H., Zhang, S., Bellouin, N., Guttikunda, S. K., Hopke, P. K., Jacobson, M. Z., Kaiser, J. W., Klimont, Z., Lohmann, U., Schwarz, J. P., Shindell, D., Storelvmo, T., Warren, S. G., and Zender, C. S.: Bounding the role of black carbon in the climate system: a scientific assessment, J. Geophys. Res.Atmos., 118, 5380-5552, 2013.

Canagaratna, M. R., Jayne, J. T., Ghertner, D. A., Herndon, S., Shi, Q., Jimenez, J. L., Silva, P. J., Williams, P., Lanni, T., Drewnick, F., Demerjian, K. L., Kolb, C. E., and Worsnop, D. R.:
Chase studies of particulate emissions from in-use New York City vehicles, Aerosol Sci. Tech., 38, 555-573, 2004.

Cappa, C. D., Onasch, T. B., Massoli, P., Worsnop, D. R., Bates, T. S., Cross, E. S., Davidovits, P., Hakala, J., Hayden, K. L., Jobson, B. T., Kolesar, K. R., Lack, D. A., Lerner, B. M., Li, S. M., Mellon, D., Nuaaman, I., Olfert, J. S., Petaja, T., Quinn, P. K., Song, C., Subramanian, R., Williams, E. J., and Zaveri, R. A.: Radiative absorption enhancements due to the mixing state of atmospheric black carbon, Science, 337, 1078-1081, 2012.

Chan, T. W., Brook, J. R., Smallwood, G. J., and Lu, G.: Time-resolved measurements of black carbon light absorption enhancement in urban and near-urban locations of southern Ontario, Canada, Atmos. Chem. Phys., 11, 10407-10432, doi:10.5194/acp-11-10407-2011, 2011.

Chin, M., Kahn, R., Rind, D., Feingold, G., Schwartz, S., and DeCola, P.: Atmospheric Aerosol Properties and Climate Impacts, A Report by the U.S. Climate Change Science Program and the Subcommittee on Global Change Research, Tech. Rep. SAP 2.3, NASA, Washington, DC, 2009.

China, S., Salvadori, N., and Mazzoleni, C.: Effect of traffic and driving characteristics on morphology of atmospheric soot particles at freeway on-ramps, Environ. Sci. Technol., 48, 3128-3135, 2014.

China, S., Scarnato, B., Owen, R., Zhang, B., Ampadu, M., Kumar, S., Dzepina, K., Dziobak, M., Fialho, P., Perlinger, J., Hueber, J., D. Helmig, Mazzoleni, L., and Mazzoleni, C.: Morphology and mixing state of aged soot particles at a remote marine free troposphere site: implications for optical properties, Geophys. Res. Lett., 42, 1243-1250, 2015.

Chirico, R., DeCarlo, P. F., Heringa, M. F., Tritscher, T., Richter, R., Prévôt, A. S. H., Dommen, J., Weingartner, E., Wehrle, G., Gysel, M., Laborde, M., and Baltensperger, U.: Impact of aftertreatment devices on primary emissions and secondary organic aerosol formation potential from in-use diesel vehicles: results from smog chamber experiments, Atmos. Chem. Phys., 10, 11545-11563, doi:10.5194/acp-10-11545-2010, 2010.

Chung, S. H. and Seinfeld, J. H.: Climate response of direct radiative forcing of anthropogenic black carbon, J. Geophys. Res.Atmos., 110, D11102, doi:10.1029/2004JD005441, 2005.

Corbin, J. C., Sierau, B., Gysel, M., Laborde, M., Keller, A., Kim, J., Petzold, A., Onasch, T. B., Lohmann, U., and Mensah, A. A.: Mass spectrometry of refractory black carbon particles from six sources: carbon-cluster and oxygenated ions, Atmos. Chem. Phys., 14, 2591-2603, doi:10.5194/acp-14-2591-2014, 2014

Cross, E. S., Onasch, T. B., Canagaratna, M., Jayne, J. T., Kimmel, J., Yu, X.-Y., Alexander, M. L., Worsnop, D. R., and Davidovits, P.: Single particle characterization using a light scattering module coupled to a time-of-flight aerosol mass spectrometer, Atmos. Chem. Phys., 9, 7769-7793, doi:10.5194/acp-9-7769-2009, 2009.

Dallmann, T. R., Onasch, T. B., Kirchstetter, T. W., Worton, D. R., Fortner, E. C., Herndon, S. C., Wood, E. C., Franklin, J. P., Worsnop, D. R., Goldstein, A. H., and Harley, R. A.: Characterization of particulate matter emissions from on-road gasoline and diesel vehicles using a soot particle aerosol mass spectrometer, Atmos. Chem. Phys., 14, 7585-7599, doi:10.5194/acp-14-75852014, 2014. 
DeVille, R., Riemer, N., and West, M.: Weighted Flow Algorithms (WFA) for stochastic particle coagulation, J. Comput. Phys., 230, 8427-8451, 2011.

Fast, J. D., Gustafson, W. I., Easter, R. C., Zaveri, R. A., Barnard, J. C., Chapman, E. G., Grell, G. A., and Peckham, S. E.: Evolution of ozone, particulates, and aerosol direct radiative forcing in the vicinity of Houston using a fully coupled meteorology-chemistry-aerosol model, J. Geophys. Res.-Atmos., 111, D21305, doi:10.1029/2005JD006721, 2006.

Flowers, B. A., Dubey, M. K., Mazzoleni, C., Stone, E. A., Schauer, J. J., Kim, S.-W., and Yoon, S. C.: Optical-chemicalmicrophysical relationships and closure studies for mixed carbonaceous aerosols observed at Jeju Island; 3-laser photoacoustic spectrometer, particle sizing, and filter analysis, Atmos. Chem. Phys., 10, 10387-10398, doi:10.5194/acp-10-10387-2010, 2010.

Freutel, F., Drewnick, F., Schneider, J., Klimach, T., and Borrmann, S.: Quantitative single-particle analysis with the Aerodyne aerosol mass spectrometer: development of a new classification algorithm and its application to field data, Atmos. Meas. Tech., 6, 3131-3145, doi:10.5194/amt-6-3131-2013, 2013.

Gysel, M., Laborde, M., Olfert, J. S., Subramanian, R., and Gröhn, A. J.: Effective density of Aquadag and fullerene soot black carbon reference materials used for SP2 calibration, Atmos. Meas. Tech., 4, 2851-2858, doi:10.5194/amt-4-2851-2011, 2011.

Healy, R. M., Sciare, J., Poulain, L., Kamili, K., Merkel, M., Müller, T., Wiedensohler, A., Eckhardt, S., Stohl, A., Sarda-Estève, R., McGillicuddy, E., O'Connor, I. P., Sodeau, J. R., and Wenger, J. C.: Sources and mixing state of size-resolved elemental carbon particles in a European megacity: Paris, Atmos. Chem. Phys., 12, 1681-1700, doi:10.5194/acp-12-1681-2012, 2012.

Healy, R. M., Wang, J. M., Jeong, C.-H., Lee, A. K. Y., Willis, M. D., Jaroudi, E., Zimmerman, N., Hilker, N., Murphy, M., Eckhardt, S., Stohl, A., Abbatt, J. P. D., Wenger, J. C., and Evans, G. J.: Light-absorbing properties of ambient black carbon and brown carbon from fossil fuel and biomass burning sources, J. Geophys. Res.-Atmos., 120, 6619-6633, doi:10.1002/2015JD023382, 2015.

Jacobson, M. Z.: A physically-based treatment of elemental carbon optics: implications for global direct forcing of aerosols, Geophys. Res. Lett., 27, 217-220, doi:10.1029/1999GL010968, 2000 .

Jacobson, M. Z.: Strong radiative heating due to the mixing state of black carbon in atmospheric aerosols, Nature, 409, 695-697, 2001.

Jimenez, J. L., Jayne, J. T., Shi, Q., Kolb, C. E., Worsnop, D. R., Yourshaw, I., Seinfeld, J. H., Flagan, R., Zhang, X., Smith, K., Morris, J., and Davidovits, P.: Ambient aerosol sampling using the Aerodyne Aerosol Mass Spectrometer, J. Geophys. Res.Atmos., 108, 8425, doi:10.1029/2001JD001213, 2003.

Johnson, K. S., Zuberi, B., Molina, L. T., Molina, M. J., Iedema, M. J., Cowin, J. P., Gaspar, D. J., Wang, C., and Laskin, A.: Processing of soot in an urban environment: case study from the Mexico City Metropolitan Area, Atmos. Chem. Phys., 5, 3033-3043, doi:10.5194/acp-5-3033-2005, 2005.

Knox, A., Evans, G. J., Brook, J. R., Yao, X., Jeong, C. H., Godri, K. J., Sabaliauskas, K., and Slowik, J. G.: Mass absorption cross-section of ambient black carbon aerosol in relation to chemical age, Aerosol Sci. Tech., 43, 522-532, 2009.
Kuwata, M., Kondo, Y., and Takegawa, N.: Critical condensed mass for activation of black carbon as cloud condensation nuclei in Tokyo, J. Geophys. Res.-Atmos., 114, D20202, doi:10.1029/2009JD012086, 2009.

Laborde, M., Crippa, M., Tritscher, T., Jurányi, Z., Decarlo, P. F., Temime-Roussel, B., Marchand, N., Eckhardt, S., Stohl, A., Baltensperger, U., Prévôt, A. S. H., Weingartner, E., and Gysel, M.: Black carbon physical properties and mixing state in the European megacity Paris, Atmos. Chem. Phys., 13, 5831-5856, doi:10.5194/acp-13-5831-2013, 2013.

Lack, D. A., Langridge, J. M., Bahreini, R., Cappa, C. D., Middlebrook, A. M., and Schwarz, J. P.: Brown carbon and internal mixing in biomass burning particles, P. Natl. Acad. Sci. USA, 109, 14802-14807, 2012.

Lee, A. K. Y., Willis, M. D., Healy, R. M., Onasch, T. B., and Abbatt, J. P. D.: Mixing state of carbonaceous aerosol in an urban environment: single particle characterization using the soot particle aerosol mass spectrometer (SP-AMS), Atmos. Chem. Phys., 15, 1823-1841, doi:10.5194/acp-15-1823-2015, 2015a.

Lee, A. K. Y., Willis, M. D., Healy, R. M., Wang, J. M., Jeong, C.H., Wenger, J. C., Evans, G. J., and Abbatt, J. P. D.: Single particle characterization of biomass burning organic aerosol (BBOA): evidence for non-uniform mixing of high molecular weight organics and potassium, Atmos. Chem. Phys. Discuss., 15, $32157-$ 32183, doi:10.5194/acpd-15-32157-2015, 2015b.

Liu, D., Allan, J., Whitehead, J., Young, D., Flynn, M., Coe, H., McFiggans, G., Fleming, Z. L., and Bandy, B.: Ambient black carbon particle hygroscopic properties controlled by mixing state and composition, Atmos. Chem. Phys., 13, 2015-2029, doi:10.5194/acp-13-2015-2013, 2013.

Liu, D., Allan, J. D., Young, D. E., Coe, H., Beddows, D., Fleming, Z. L., Flynn, M. J., Gallagher, M. W., Harrison, R. M., Lee, J., Prevot, A. S. H., Taylor, J. W., Yin, J., Williams, P. I., and Zotter, P.: Size distribution, mixing state and source apportionment of black carbon aerosol in London during wintertime, Atmos. Chem. Phys., 14, 10061-10084, doi:10.5194/acp14-10061-2014, 2014.

Liu, P. F., Zhao, C. S., Göbel, T., Hallbauer, E., Nowak, A., Ran, L., Xu, W. Y., Deng, Z. Z., Ma, N., Mildenberger, K., Henning, S., Stratmann, F., and Wiedensohler, A.: Hygroscopic properties of aerosol particles at high relative humidity and their diurnal variations in the North China Plain, Atmos. Chem. Phys., 11, 3479-3494, doi:10.5194/acp-11-3479-2011, 2011.

Liu, S., Russell, L. M., Sueper, D. T., and Onasch, T. B.: Organic particle types by single-particle measurements using a time-offlight aerosol mass spectrometer coupled with a light scattering module, Atmos. Meas. Tech., 6, 187-197, doi:10.5194/amt-6187-2013, 2013.

Liu, S., Aiken, A. C., Gorkowski, K., Dubey, M., Cappa, C. D., Williams, L. R., Herndon, S. C., Massoli, P., Fortner, E. C., Chhabra, P., Brooks, W., Onasch, T. B., Jayne, J. T., Worsnop, D., China, S., Sharma, N., Mazzoleni, C., Xu, L., Ng, N., Liu, D., Allan, J. D. Lee, J., Fleming, Z. L. Mohr, C., Zotter, P., Szidat, P., and Prevot, A. S. H.: Enhanced light absorption by mixed source black and brown carbon particles in UK winter, Nature Communications, 6, 8435, doi:10.1038/ncomms9435, 2015.

Maricq, M. M. and Ning, X.: The effective density and fractal dimension of soot particles from premixed flames and motor vehicle exhaust, Journal of Aerosol Science, 35, 1251-1274, 2004. 
Massoli, P., Fortner, E. C., Canagaratna, M. R., Williams, L. R., Zhang, Q., Sun, Y., Schwab, J. J., Trimborn, A., Onasch, T. B., Demerjian, K. L., Kolb, C. E., Worsnop, D. R., and Jayne, J. T.: Pollution gradients and chemical characterization of particulate matter from vehicular traffic near major roadways: results from the 2009 Queens College Air Quality Study in NYC, Aerosol Sci. Tech., 46, 1201-1218, 2012.

Matsui, H., Koike, M., Kondo, Y., Moteki, N., Fast, J. D., and Zaveri, R. A.: Development and validation of a black carbon mixing state resolved three-dimensional model: aging processes and radiative impact, J. Geophys. Res.-Atmos., 118, 2304-2326, doi:10.1029/2012JD018446, 2013.

McComiskey, A., Schwartz, S., Schmid, B., Guan, H., Lewis, E., Ricchiazzi, P., and Ogren, J.: Direct aerosol forcing: calculation from observables and sensitivities to inputs, J. Geophys. Res., 113, D09202, doi:10.1029/2007JD009170, 2008.

McMeeking, G. R., Good, N., Petters, M. D., McFiggans, G., and Coe, H.: Influences on the fraction of hydrophobic and hydrophilic black carbon in the atmosphere, Atmos. Chem. Phys., 11, 5099-5112, doi:10.5194/acp-11-5099-2011, 2011a.

McMeeking, G. R., Morgan, W. T., Flynn, M., Highwood, E. J., Turnbull, K., Haywood, J., and Coe, H.: Black carbon aerosol mixing state, organic aerosols and aerosol optical properties over the United Kingdom, Atmos. Chem. Phys., 11, 9037-9052, doi:10.5194/acp-11-9037-2011, $2011 \mathrm{~b}$.

Michelotti, M., Heath, M., and West, M.: Binning for efficient stochastic multiscale particle simulations, Multiscale Model Sim., 11, 1071-1096, 2013.

Moffet, R. C. and Prather, K. A.: In-situ measurements of the mixing state and optical properties of soot with implications for radiative forcing estimates, P. Natl. Acad. Sci. USA, 106, 11872 11877, 2009.

Mohr, C., Huffman, J. A., Cubison, M. J., Aiken, A. C., Docherty, K. S., Kimmel, J. R., Ulbrich, I. M., Hannigan, M., and Jimenez, J. L.: Characterization of primary organic aerosol emissions from meat cooking, trash burning, and motor vehicles with high-resolution aerosol mass spectrometry and comparison with ambient and chamber observations, Environ. Sci. Technol., 43, 2443-2449, 2009.

Moosmüller, H., Chakrabarty, R., and Arnott, W.: Aerosol light absorption and its measurement: A review, J Quant. Spectrosc. RA, 110, 844-878, doi:10.1016/j.jqsrt.2009.02.035, 2009.

Moteki, N., Kondo, Y., Miyazaki, Y., Takegawa, N., Komazaki, Y., Kurata, G., Shirai, T., Blake, D. R., Miyakawa, T., and Koike, M.: Evolution of mixing state of black carbon particles: aircraft measurements over the western Pacific in March 2004, Geophys. Res. Lett., 34, L11803, doi:10.1029/2006GL028943, 2007.

Onasch, T. B., Trimborn, A., Fortner, E. C., Jayne, J. T., Kok, G. L., Williams, L. R., Davidovits, P., and Worsnop, D. R.: Soot particle aerosol mass spectrometer: development, validation, and initial application, Aerosol Sci. Tech., 46, 804-817, 2012.

Oshima, N., Koike, M., Zhang, Y., and Kondo, Y.: Aging of black carbon in outflow from anthropogenic sources using a mixing state resolved model: 2. Aerosol optical properties and cloud condensation nuclei activities, J. Geophys. Res.-Atmos., 114, D18202, doi:10.1029/2008JD011681, 2009.

Paatero, P. and Tapper, U.: Positive matrix factorization: a nonnegative factor model with optimal utilization of error estimate of data values, Environmetrics, 5, 111-126, 1994.
Ramanathan, V. and Carmichael, G.: Global and regional climate changes due to black carbon, Nat. Geosci., 1, 221-227, 2008.

Riemer, N., West, M., Zaveri, R. A., and Easter, R. C.: Simulating the evolution of soot mixing state with a particleresolved aerosol model, J. Geophys. Res.-Atmos., 114, D09202, doi:10.1029/2008JD011073, 2009.

Sabaliauskas, K., Jeong, C.-H., Yao, X., and Evans, G. J.: The application of wavelet decomposition to quantify the local and regional sources of ultrafine particles in cities, Atmos. Environ., 95, 249-257, doi:10.1016/j.atmosenv.2014.05.035, 2014.

Sage, A. M., Weitkamp, E. A., Robinson, A. L., and Donahue, N. M.: Evolving mass spectra of the oxidized component of organic aerosol: results from aerosol mass spectrometer analyses of aged diesel emissions, Atmos. Chem. Phys., 8, 1139-1152, doi:10.5194/acp-8-1139-2008, 2008.

Scarnato, B. V., Vahidinia, S., Richard, D. T., and Kirchstetter, T. W.: Effects of internal mixing and aggregate morphology on optical properties of black carbon using a discrete dipole approximation model, Atmos. Chem. Phys., 13, 5089-5101, doi:10.5194/acp-13-5089-2013, 2013.

Schneider, J., Weimer, S., Drewnick, F., Borrmann, S., Helas, G., Gwaze, P., Schmid, O., Andreae, M. O., and Kirchner, U.: Mass spectrometric analysis and aerodynamic properties of various types of combustion-related aerosol particles, Int. J. Mass Spectrom., 258, 37-49, 2006.

Seuper, D.: ToF-AMS analysis software, available at: http://cires.colorado.edu/jimenez-group/ToFAMSResources/ ToFSoftware/index.html (last access: 24 September 2015), 2010.

Shindell, D., Kuylenstierna, J. C. I., Vignati, E., van Dingenen, R., Amann, M., Klimont, Z., Anenberg, S. C., Muller, N., JanssensMaenhout, G., Raes, F., Schwartz, J., Faluvegi, G., Pozzoli, L., Kupiainen, K., Hoglund-Isaksson, L., Emberson, L., Streets, D., Ramanathan, V., Hicks, K., Oanh, N. T. K., Milly, G., Williams, M., Demkine, V., and Fowler, D.: Simultaneously mitigating near-term climate change and improving human health and food security, Science, 335, 183-189, 2012.

Shiraiwa, M., Kondo, Y., Moteki, N., Takegawa, N., Sahu, L. K., Takami, A., Hatakeyama, S., Yonemura, S., and Blake, D. R.: Radiative impact of mixing state of black carbon aerosol in Asian outflow, J. Geophys. Res.-Atmos., 113, D24210, doi:10.1029/2008JD010546, 2008.

Toner, S. M., Sodeman, D. A., and Prather, K. A.: Single particle characterization of ultrafine and accumulation mode particles from heavy duty diesel vehicles using aerosol time-of-flight mass spectrometry, Environ. Sci. Technol., 40, 3912-3921, 2006.

Tritscher, T., Juranyi, Z., Martin, M., Chirico, R., Gysel, M., Heringa, M. F., DeCarlo, P. F., Sierau, B., Prevot, A. S. H., Weingartner, E., and Baltensperger, U.: Changes of hygroscopicity and morphology during ageing of diesel soot, Environ. Res. Lett., 6, 034026, doi:10.1088/1748-9326/6/3/034026, 2011.

Ulbrich, I. M., Canagaratna, M. R., Zhang, Q., Worsnop, D. R., and Jimenez, J. L.: Interpretation of organic components from Positive Matrix Factorization of aerosol mass spectrometric data, Atmos. Chem. Phys., 9, 2891-2918, doi:10.5194/acp-9-2891-2009, 2009.

Wang, J. M., Jeong, C.-H., Zimmerman, N., Healy, R. M., Wang, D. K., Ke, F., and Evans, G. J.: Plume-based analysis of vehicle fleet air pollutant emissions and the contribu- 
tion from high emitters, Atmos. Meas. Tech., 8, 3263-3275, doi:10.5194/amt-8-3263-2015, 2015.

Willis, M. D., Lee, A. K. Y., Onasch, T. B., Fortner, E. C., Williams, L. R., Lambe, A. T., Worsnop, D. R., and Abbatt, J. P. D.: Collection efficiency of the soot-particle aerosol mass spectrometer (SP-AMS) for internally mixed particulate black carbon, Atmos. Meas. Tech., 7, 4507-4516, doi:10.5194/amt-7-4507-2014, 2014.

Zaveri, R. A. and Peters, L. K.: A new lumped structure photochemical mechanism for large-scale applications, J. Geophys. Res.Atmos., 104, 30387-30415, doi:10.1029/1999JD900876, 1999.

Zaveri, R. A., Easter, R. C., and Peters, L. K.: A computationally efficient multicomponent equilibrium solver for aerosols (MESA), J. Geophys. Res.-Atmos., 110, D24203, doi:10.1029/2004JD005618, 2005a.

Zaveri, R. A., Easter, R. C., and Wexler, A. S.: A new method for multicomponent activity coefficients of electrolytes in aqueous atmospheric aerosols, J. Geophys. Res.-Atmos., 110, D02201, doi:10.1029/2004JD004681, 2005b.

Zaveri, R. A., Easter, R. C., Fast, J. D., and L. K., P.: Model for Simulating Aerosol Interactions and Chemistry (MOSAIC), J. Geophys. Res., 113, 13204, doi:10.1029/2007JD008782, 2008.

Zaveri, R., Barnard, J., Easter, R., Riemer, N., and West, M.: Particle-resolved simulation of aerosol size, composition, mixing state, and the associated optical and cloud condensation nuclei activation properties in an evolving urban plume, J. Geophys. Res., 115, D17210, doi:10.1029/2009JD013616, 2010.
Zhang, G., Bi, X., Li, L., Chan, L. Y., Li, M., Wang, X., Sheng, G., Fu, J., and Zhou, Z.: Mixing state of individual submicron carbon-containing particles during spring and fall seasons in urban Guangzhou, China: a case study, Atmos. Chem. Phys., 13, 4723-4735, doi:10.5194/acp-13-4723-2013, 2013.

Zhang, Q., Jimenez, J. L., Canagaratna, M. R., Ulbrich, I. M., $\mathrm{Ng}$, N., Worsnop, D., and Sun, Y.: Understanding atmospheric organic aerosols via factor analysis of aerosol mass spectrometry: a review, Anal. Bioanal. Chem., 401, 3045-3067, doi:10.1007/s00216-011-5355-y, 2011.

Zhang, R. Y., Khalizov, A. F., Pagels, J., Zhang, D., Xue, H. X., and McMurry, P. H.: Variability in morphology, hygroscopicity, and optical properties of soot aerosols during atmospheric processing, P. Natl. Acad. Sci. USA, 105, 10291-10296, 2008.

Zhao, C., Liu, X., Qian, Y., Yoon, J., Hou, Z., Lin, G., McFarlane, S., Wang, H., Yang, B., Ma, P.-L., Yan, H., and Bao, J.: A sensitivity study of radiative fluxes at the top of atmosphere to cloudmicrophysics and aerosol parameters in the community atmosphere model CAM5, Atmos. Chem. Phys., 13, 10969-10987, doi:10.5194/acp-13-10969-2013, 2013. 